\title{
〔第36回総会シンポジゥム】
}

\section{IV. 治療時の技術的諸問題}

国立病院九州㤁九セン夕一放射線治療部

熊 谷 孝 三

\section{TECHNICAL PROBLEMS OF HIGH DOSE RATE INTRACAVITARY RADIATION THERAPY USING REMOTE AFTERLOADER}

\author{
By KOZO KUMAGAI \\ Department of radiology, National \\ Cancer Center Hospital of Kyushu.
}

\section{Summary}

The important factors to use remote afterloading system (RALS) are to calculated the correct radiation dose distribution, to deliver the exact dose to point $A$, to minimize the radiation injury, and to operate the cycling source with safety and accuracy.

Therefore, we need to have excelent method for radiotherapy and perfect system for the safety.

The next steps are as follows,

(1) Equipment and staff (Radiotherapist, Radiophysicist, Radiotechnologist).

(2) Safety care and exposure dose.

(3) Training program and educational system from the international point of view.

Key Wards : Remote afterloading system, Intracavitary radiation therapeutic technology, Technical ploblems.

\section{1. 緒 言}

U. K. Henschke が1964年に高線舅率遠隔操作式腔内 照射装置 (Remote afterloader) について報告して以来, これの普及はめざましい. Remote afterloader として, Cathetron (英), Brachytron (fol), Cervitron (米), Afterloading-Gerät Buchler (独), Ralstron (鼠津), Remote afterloading-Ral (東芝) などがあり，術者の放 射線被曝，患者の苦痛，線源位置の移動，放素病棟管理 などの問題が解決された。 また，他に從来の ${ }^{226} \mathrm{Ra}$ 乙同 稼て低線量率腔内照射をべット・サイドで行うCurietron (仏), Gynatron (仏), Selectron (英) などもあ る.
ことで言及する Remote afterloader は，線源強度か キュリオーダのため線源近浐の線量測定が困難であり, 各装置についてA点線量，線量分有のばらつきが想さ れる。また，経時的な装置の賣耗に刘して，敛重な保守 管理を行わなければ被曝防止の利益は失われ，危険な被

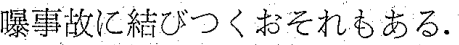

Remote afterloader の治療時に打ける最も重要な問題 は，琵想的な線量分扸の作成㲸って，A点線量を正確 に把层し，障害を最小限にとめて，できるだけ高い治療 可能比を得，かつ線源を確奏に送厌できるという点にあ 万.

我々は, 現在までの使用経験から, Remote afterloader のいくつかの技術的な開題について検討したので報告す 
る.

\section{2. 線源, 線源カプセル, および 模擬線源}

\section{1 線源，線源カプセルの具備すべき条件}

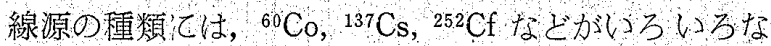
形状や材料のカプセルに封入，使用されるが，使用目的 にそった形状，寸法が必要であり，長期間にわたって妿 全代使用されなけれ独ならない。

線源，線源力プセルの具借すべき条件は，つぎのよう な事項について十分考慮されたものでなけれはならな 4.

(1) 線源

(1) 正常な使用状態乙执して，逸脱，また保破堎され るおそれのないとと。

(2) 漏洩，漫透などにより散逸して活染するおをれの ないてと.

（2）線源カプセル

(1) 使用環境に十分而えること（使用中に起とり得る 生力, 温变, および化学的現象など)

(2) 内容物加らの影響记強りとと（線源㲸よる化学的 笍食，圧力堌加，放射線損傷など).

\section{2 線源, 線源カプセルの実際}

線源は，ほとんどの装置に扑て ${ }^{60} \mathrm{Co}$ pellet type が 使用されている。線源仕様を Table 1 亿示す。線源は, ${ }^{60} \mathrm{Co}$ pellet $20 \sim 30$ 粒の中方方放射能のできるだけ等し 认ものを選択し，ステンレス製カプセル (SUS-316L) に 封入される. 各施設加らの線源強度の指定量とRI 協会 の封入量の唄差証高土 $10 \%$ であり，実際には，指定量 よりも多く封大されている場合が多い。 線源仕様書に明 記されている空間線量率の測定値の信頼性は高く（文部 省科咞重松班報告)，てのようなデータを得るためには， 慓準的な測定法の確立が必要である己同時に，各施設に
おいて夷測による確認を行わなければならなる。

線源の安全性沉つてて，国際的汇関心があたれ，圧

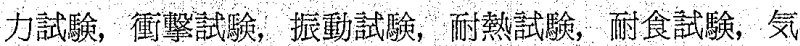
泡試験，浸清試験などの安全性試驗为行われている。ま た，線源カプセルの先端部は，污染，漏出防止の目的で アルゴン溶接されている.

\section{3 模擬線源}

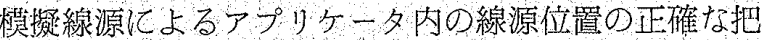
握は，線量計算の精度に関して最も基礎的な要因であ る.

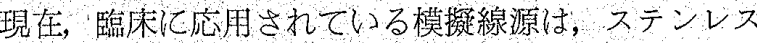
製のため，線源位置を明確汇把握するてとができない。 そてで, Fig. 1飞示すように, 線源カプセル内の線源位 置晹確に半定でき, かつ over ride 方式の線源配列に 応じた模擬線源が本来必要である. Fig. 2 亿, 従来のス テンレス製（左 3 本），およびわれわれが使用している 模擬線源（右 5 本）を示した. Fig. 3 は，乙れを使用し た場合の位置決め写真で，線源位置力明確记判定され， 線源から任意の点までの距離を正確，容易䎲計測するて とができる。

\section{4 線源位置のチェック}

アプリケータ内部の線源位置を確談するには，模擬線 源の目視てよる方法と線源嚗射によるフィルム法とがあ

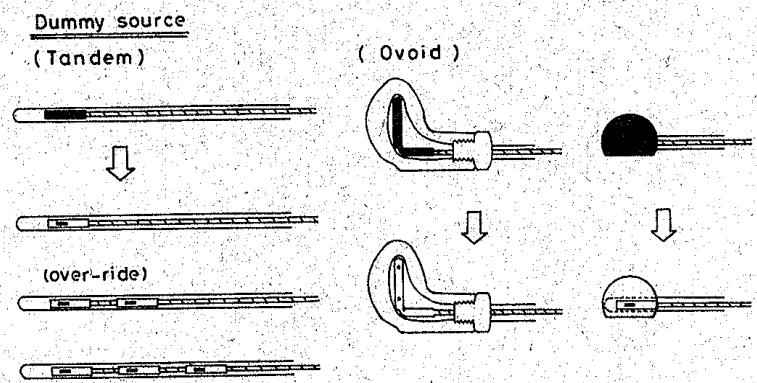

Fig. 1 Dummy source.
Table $1{ }^{60} \mathrm{Co}$ pellet type source and capsule.

\begin{tabular}{|c|c|c|}
\hline & Co -60 湶源 & 線 \\
\hline 線源 の形状 & 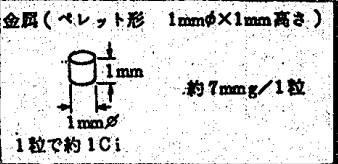 & 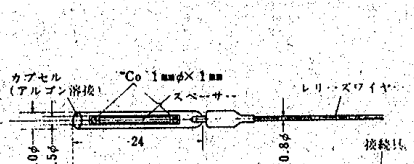 \\
\hline 比 放 射 能 & $161 \sim 180 \mathrm{ci} / \mathrm{g}$ & $2+-170$ \\
\hline 1 粒あたりの重量 & 約 $7 \mathrm{mg}$ & 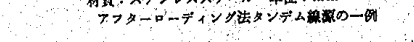 \\
\hline 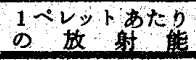 & $1.1 \sim 1.2 \mathrm{ci}$ & \\
\hline
\end{tabular}

る. 前者は, 比較的容易て あり，後者は，遮光したフ イルムをまず目視によって ピンホールを開孔し，次い で線源曝射を行い,アアプリ ケータ先端，側壁からの線 源位跙, および over ride 間隔を確談する (Fig. 4 上 図).との場合は, micro photometer を使用して, 正 確な線源位監を求好ると 


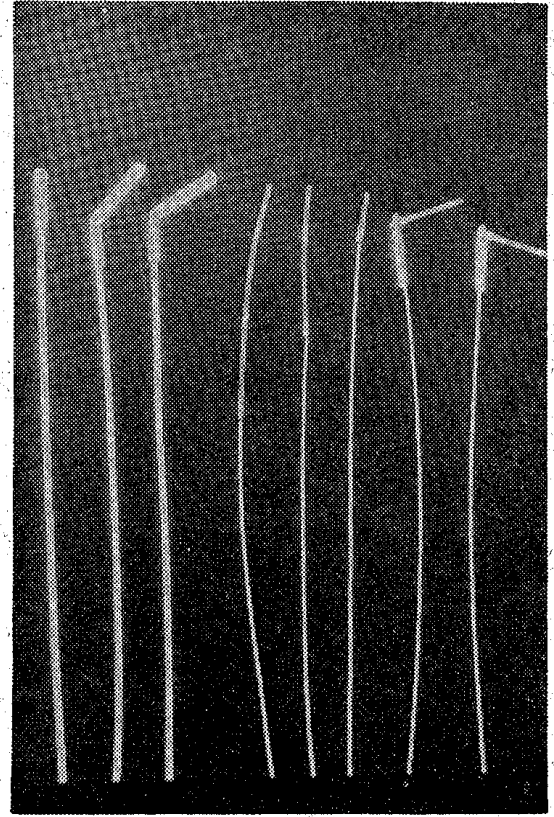

Fig. 2 Our dummy source are shown on the right. On the left are shown usual dummy source.

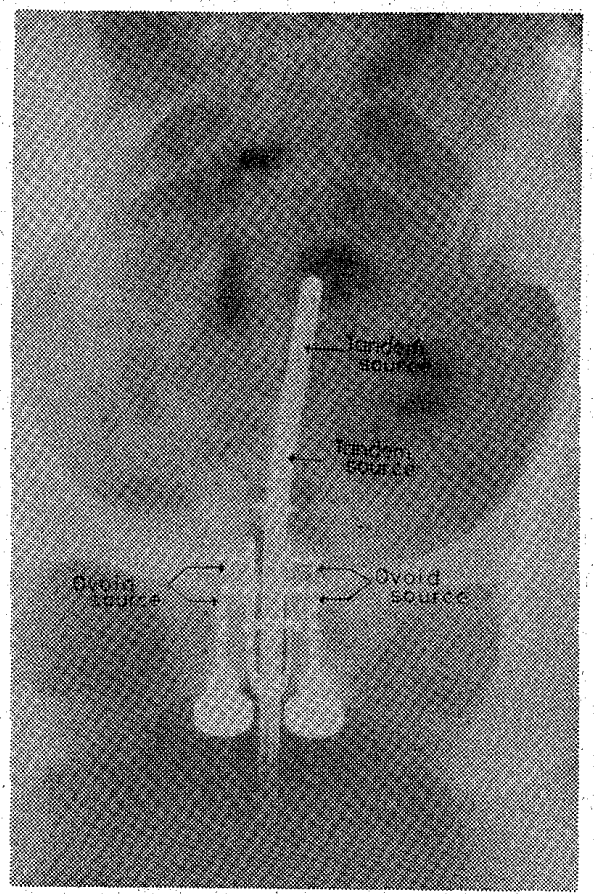

Fig. 3 Photograph of X-ray simulation with our dummy source.

ができる (Fig. 4 下図)。

\section{3. アプリケータ}

アプリケータは，通常子宮腔内線源用 (タンデム), 腟 内線源用（オボイド）からなる，タンデム篦とついては，

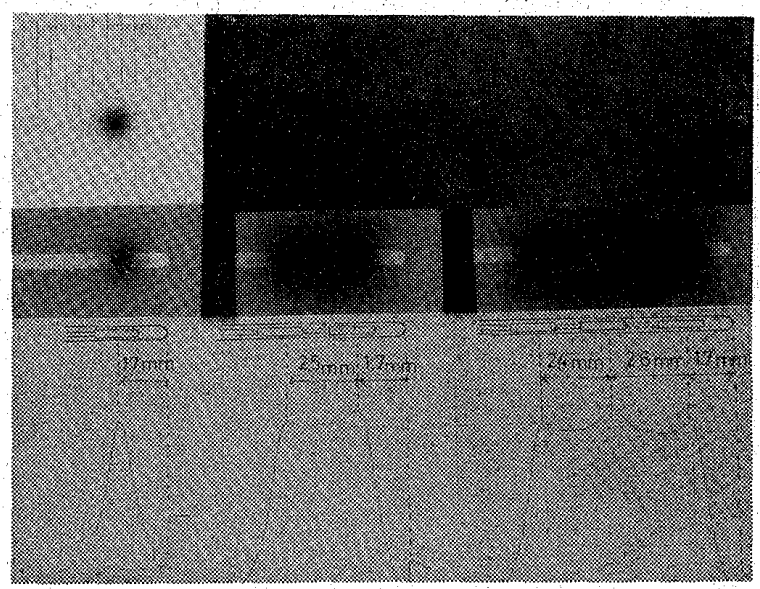

Fig. 4 The method of source check.

子宮の傾斜に応して可動性をもたせたポリエチレン製 (TAO 式) と種々の子宮腔内長, 曲加り角の金属（ステ ンレス) 製とがある、標準型オボイドは，胵円蓋の広さ に応してて左右雨線源間隔が開大でき，材質はアルミニウ ム製とアクリル樹脂製とがある。乙れら而者の比較を，

Table 2(a)，(b)飞示した われわれが試作した金属ア プリケータは，子宮の可動性怔失なわれておらず，出血 が少ない症例て使用しており，子宮位置の矯正による線 量分布の均等化を目的としている.

Table 3 は，子宮造影，ポリェチレンアプリケータ， 金属製アプりケータ使用時の体軸に対する子篦軸の傾斜 角を比較しだので，特亿，金属製アプリケータは子宮 軸の左右の傾きを容易に矯正することができる.

\section{4. 装置構 成}

装監構成は，Fig. 5 《示すように，線源，アプリケー 夕の他て照射器，支持器，操作器，これらを結ぶ案内管， 治療台；位置決装置，監視装置より構成されている。

Table 4(a)，(b)は, 各装置 (Cathetron, Brachyron, Ralstron, Ral.) の比較である. 使用線源恃, ${ }^{60}$ Co pellet type であるが pencile type を使用した装置もある。線源容器 の線源収納孔数が 3 孔の装置では, 線源位置確認用の模

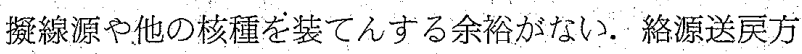
式は，ギャを使用したレリーズワイヤによる方法とロー ラによる压送フリクションドライブ方式などがある。線 源移動方式/，反復運動を行う oscillation 方式と over ride 方式があり，前者は，長時間の反復運動のタイムラ グにより両端が過線量になる久点がある。後者は，备点 の照射時間と移動距離とを任意に設定するととにより， 
Table $2(a)$ Tandem applicators.

\begin{tabular}{|c|c|c|}
\hline タンーム・フフリーータの形態及ひ材筫 & 利 & 欠 \\
\hline 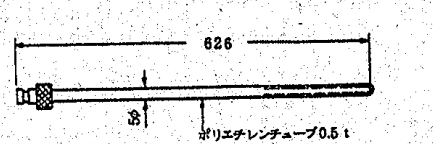 & 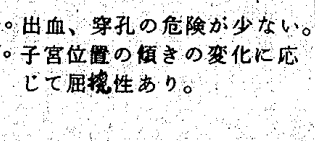 & 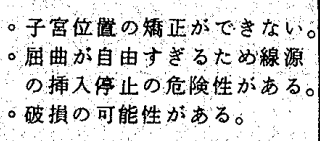 \\
\hline 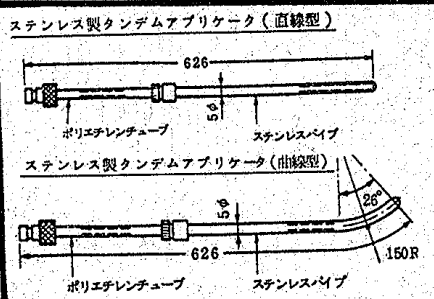 & 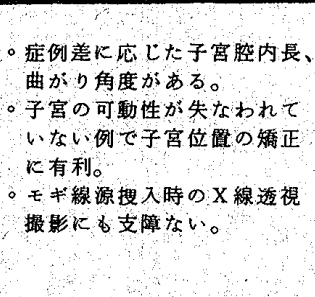 & 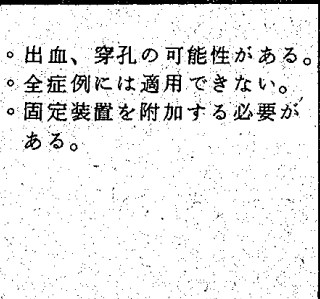 \\
\hline
\end{tabular}

Table $2(b)$ Ovoid applicator.

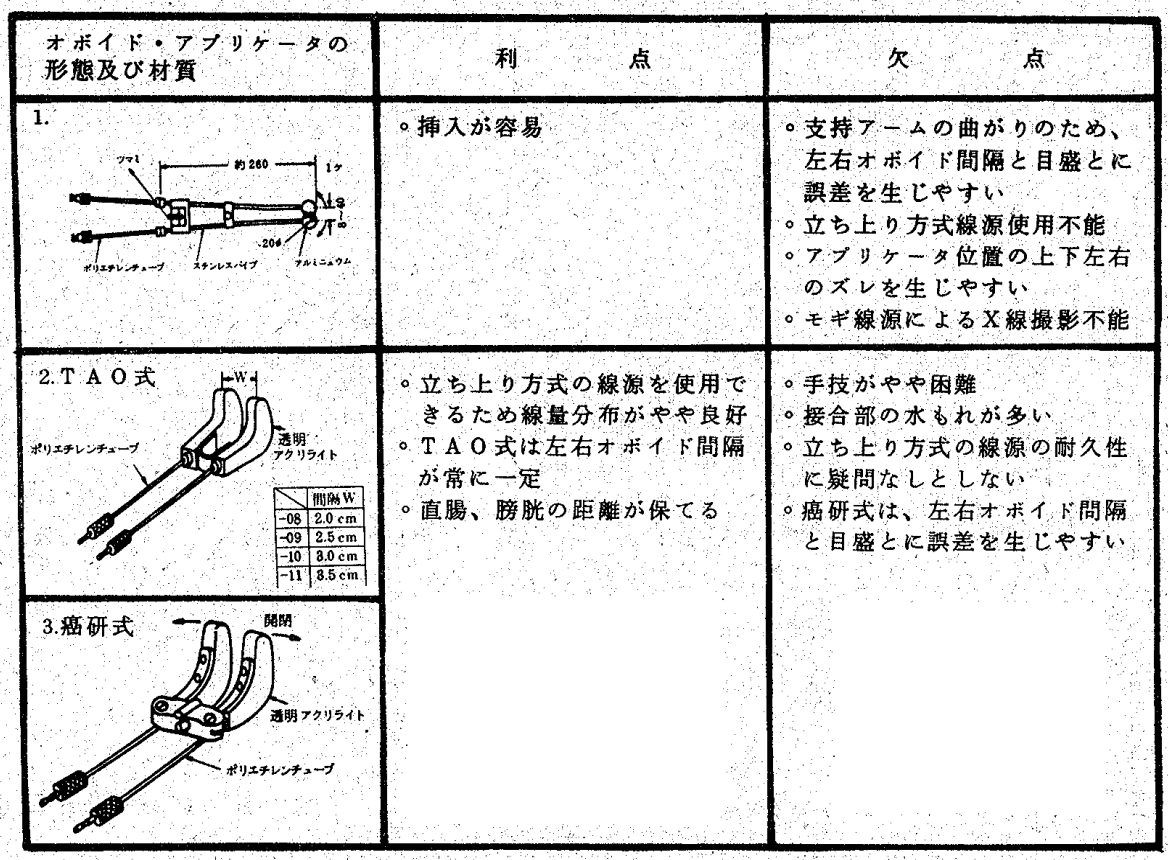

種々の線喤分布のパターン を作るととが可能である. また，停電時の安全対策と して, 手動ハンドルや重垂 イよる自動線源収納機構を 装䚚した装圆もある.

\section{5. 治療システム}

治療システムは，放射線 治療スタッフ, 没備の相違 により，各施設間に差が られる.Fig.6亿理想的な治 療システムを示した.アプ リヶー夕帾入後, 治療時の 体位で位置決め透視撮影を 行(，必要な場合はアプリ ケー夕塖入位置の修正を行 5. computer による線量計 算後, 初回治療を開始する。 また，治療時に測定した直 腸, 膀胱線量を以後の沿療 の参考しするととむある. 位置決め撮影は，線源座標 の正確な決定之適確な線量 計算を行うためであり，毎 回撮影を必要とするのはも ちろんである.アプリー 夕挿入位犆の確認を容易に するため，線源位置を透視 てきる装置が必要であり， 患者を移送して位置決め撮
Table 3 Metal tandem applicators and their advantagement.

金属(ステンレス)製タンデムアプリナータについて (適応)…..字宮位嘼矯正の目的

(子宮の可動性为失なわれておらず, 出血 6少な(症例に邀危)

体軸飞効する子宮軸の位置

\begin{tabular}{l|l|l|l}
\hline 子宫の傾斜角 & 子宮造形 & ポリエチレン製 & 金 属 製 \\
\hline 前後屈角 & $22.3 \pm 10.7^{\circ}$ & $11.4 \pm 9.1^{\circ}$ & $6.1 \pm 8.5^{\circ}$ \\
左右屈角 & $17.6 \pm 11.5^{\circ}$ & $10.1 \pm 4.8^{\circ}$ & $2.1 \pm 4.6^{\circ}$ \\
\hline
\end{tabular}

* 子宮軸の左不の傾斜を矯正するのに有利

(九州がんもター・高山による)

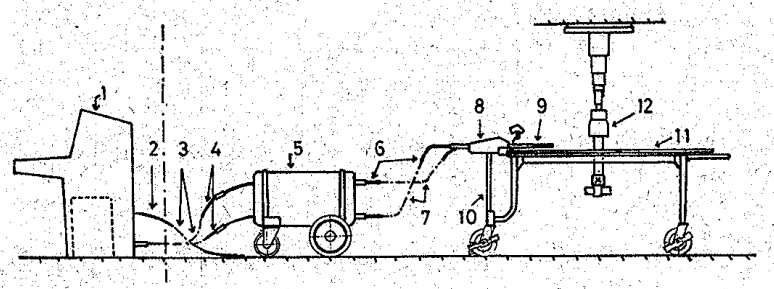

Fig. 5 Contruction of remote afterloader. 1: Controller, 2: Guide tube, 3: Drive cable, 4 : Guide tube, 5 : Source container, 6: Guide tube, 7: Drive cable, 8: Holder of applicators, and over ride unit, 9: Applicator, 10: Signal box stand, 11. Treatment stretcher, 12: X-ray unit (C-arm). 
Table 4 Comparison of performance for various remote afterloader. (Cathetron, Brachytron, Ralstron, Ral-303).

(a)

\begin{tabular}{|c|c|c|c|c|c|}
\hline 項 & 目 & C AT HE TRON & B RACYTRON & RALSTRON & RAL -303 \\
\hline \multirow{2}{*}{ 線源 } & 暒 & c $0-60$ & $c 0-60$ & $\mathrm{c} 0-60$ & c $0-60$ \\
\hline & 形：式 (m济) & ペンシル型 $(1.6 \ell \times 5)$ & ペレット型 $(1 \varnothing \times 1)$ & ペレット型 $(1 \varnothing \times 1)$ & ペレット型 $(1 \varnothing \times 1)$ \\
\hline \multirow[t]{8}{*}{ 線源容器 } & 孔 数 & 9 & 3 & 7 & 3 \\
\hline & 最大収納垁 (Ci) & 50 & 20 & 20 & 20 \\
\hline & 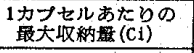 & - & 10 & 5 & 11 \\
\hline & シャッタ形式 & 迷路方讯 & 迷臨方式 & $\therefore$ 迷路方式 & $\therefore$ 迷路万式 \\
\hline & 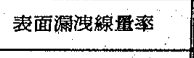 & $\begin{array}{c}10 \mathrm{mR} / \mathrm{hW} \\
\mathrm{at} \text { lm }\end{array}$ & 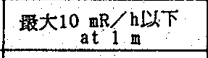 & 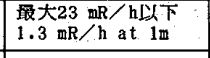 & $\begin{array}{r}8 \mathrm{mR} / \mathrm{h} \text { WF } \\
\text { at } 1 \mathrm{~m}\end{array}$ \\
\hline & 形: & キャスタ付奤形 & 設詈箱形 & キャスタ付円筒形 & 陪置箱形 \\
\hline & 霓 $\quad(\mathrm{Kg})$ & 粷 9.84 .2 & 約 500 & 䄪 850 & 粎 500 \\
\hline & 巾 $\times$ 辰 $\times$ 高cm & $66 \times 78.7 \times 109.2$ & $67.3 \times 64.8 \times 121.9$ & $.52 \times 72 \times 65.5$ & $66 \times 78.7 \times 109.2$ \\
\hline \multirow[t]{7}{*}{ 㗱作器 } & 電 源 & $200 / 230 \mathrm{~V} 50 \mathrm{~Hz} \quad 15 \mathrm{~A}$ & $115 \mathrm{~V}{ }^{50} / 60 \mathrm{~Hz} 8 \mathrm{~A}$ 篻相 & $100 \mathrm{~V}^{50} 6 \mathrm{OHz} 1 \mathrm{KVA}$ 单相 & $100 \mathrm{~V}^{50} 60 \mathrm{H} z$ KVA単相 \\
\hline & 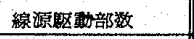 & 3 組. & 3 組 & 3 組 & 3 組: \\
\hline & 線源送杘速度 msec & 0.305 & 0.152 & $\begin{array}{l}0.14(60 \mathrm{~Hz}) \\
0.12(50 \mathrm{~Hz})\end{array}$ & $\begin{array}{l}0.16(6.0 \mathrm{~Hz}) \\
0.13(50 \mathrm{~Hz})\end{array}$ \\
\hline & 線源の移趿距離 $\mathrm{cm}$ & 約 198 & 約 198.1 & 約 310 & 約 400 \\
\hline & 線源送婜方法 & - & $\cdots-$ & レリースワイヤ ギヤ & $\begin{array}{c}\text { フリクションドライ } \\
\text { 方 式 }\end{array}$ \\
\hline & $(\mathrm{Kg})$ & 約 227 (保羁式) & 一／(床置式) & 約225（休置式) & －約 46 (卓上形) \\
\hline & 巾 $\times$ 長 $\times$ 高的 & $86.5 \times 45.7 \times 213.5$ & $121.3 \times 45.7 \times 266.7$ & $125 \times 86 \times 107$ & 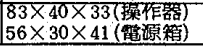 \\
\hline
\end{tabular}

(b)

\begin{tabular}{|c|c|c|c|c|c|}
\hline 項 & 目 & C AT HE TR ON & B R AC Y T RON & RALSTRON & RAL -303 \\
\hline \multirow{5}{*}{$\begin{array}{c}\text { over- } \\
\text { ride. } \\
\text { oscili } \\
\text {-ation } \\
\text { 方式 }\end{array}$} & 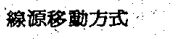 & & & & \\
\hline & & $\begin{array}{l}\text { 手野osc1llation } \\
\text { 方式 (区復運動) }\end{array}$ & 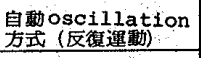 & 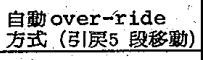 & $\begin{array}{l}\text { 自動 over-ride } \\
\text { 式 (送出5 段移動) }\end{array}$ \\
\hline & 陪定範用 & $10 \mathrm{~cm}$ & $2-16 \mathrm{~cm}$ & $\quad 15 \mathrm{~cm}$ & $10 \mathrm{~cm}$ \\
\hline & 最小媇定可能間隔 & $10 \mathrm{~cm}$ & $2 \sim 16 \mathrm{ctl}$ & $0.5 \mathrm{~cm}$ & $0.5 \mathrm{~cm}$ \\
\hline & 線源位置精度 & \pm 2 min & $\pm 1 \mathrm{~mm}$ & $\pm 2 \mathrm{~mm}$ & $\pm 1 \mathrm{~mm}$ \\
\hline \multirow{6}{*}{$\begin{array}{l}\text { 安全装置 } \\
\text { インタ } \\
\text { ロック }\end{array}$} & $\begin{array}{l}\text { 線源榙出器 } \\
\text { 線獂移勤表器 }\end{array}$ & 有 & 有 & 有: (機械的カモうシタタ） & 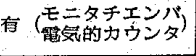 \\
\hline & 停跴時， & 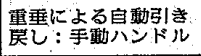 & 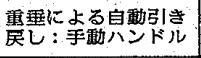 & ：手動ハンドル & 手動ハンドル \\
\hline & 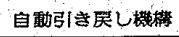 & - & - & スリップ安全機㘒 & スリップ安全機棬 \\
\hline & $\begin{array}{l}\text { アプリケータ接続 } \\
\text { 安全機栟 }\end{array}$ & - & - & 無 & 有 \\
\hline & $\begin{array}{l}\text { 案内管接紿 } \\
\text { 安金機構 }\end{array}$ & - & 有 & 有 & 有 \\
\hline & 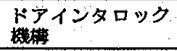 & 有 & 有 & 有 & 有 \\
\hline
\end{tabular}

法として，標準的線源配置 を栲慮した線量分布モデル チャ一トを利用する方法が ある. Table 5 亿線量計算 方法の类祭走示した。

\section{6. 線量分布}

Remote afterloader $\emptyset$ 応 用に際し，低線量率の場合 之同様な空間的線量分布の 近似がなければ，臨床上の 相互比較を行うことができ ない。

Fig. 7 は, タンデム線源 の然測值 (Radocon 555 $100 \mathrm{IC}$ ，水ファントム中）, computer (Dose pac) 0 近似計算值，および ${ }^{226} \mathrm{Ra}$ $10 \mathrm{mg}$, active length 1.5 cm)のそれぞれの線量分布 の比較で，三者は近似して

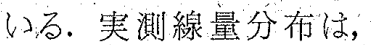
computer 計算式の線量分 布己X軸上では一致してい るが，Y軸上では約10\%減 少しており,乙れは，線源， および線源カプセルの吸收 によると侾えられる.

\section{7. 線量計算式}

Point source の近似諳算 式を下記に示す。

$$
\begin{array}{r}
D=(\mathrm{WAR} \cdot \Gamma \cdot \mathrm{Ci} \cdot \\
\left.e^{-\mu x} \cdot C_{\lambda} \cdot t\right) / d^{2}
\end{array}
$$

影を行う場合は,アプリケータの位置ずれ，脱落などに 注意しなければならず，治療体位と同姿勢で位置決め撮 影が可能な治療室設置の天俦走行式嶈垂装置などが望ま しい。また，撮影洔には，正碓な角度設定に注意を要す る.

線量計算は，最近，computer の利用怔普及し，治療 前に線源位置を修正できるようにな゙ったが, computer を 利用できる施設はなお一部施設け限られている。他の施 設では，冢測線量分布，もしくは近似計算式をもとにし た手計算が行われている：塞用的に，容易に行われる方
D: Absorbed dose

WAR: Water air ratio

(Exposure in water/Exposure in air)

$\Gamma$ : Specific gamma-ray constant $(1.35 \mathrm{R} / \mathrm{h}$ at $1 \mathrm{~m})$

Ci: Radioactivity

$e^{-\mu x}$ : Absorption of source capsule

$\mathrm{C}_{2}: \mathrm{rad} / \mathrm{R}$ conversion factor

$t$ : Exposure time

d: Distance from source 


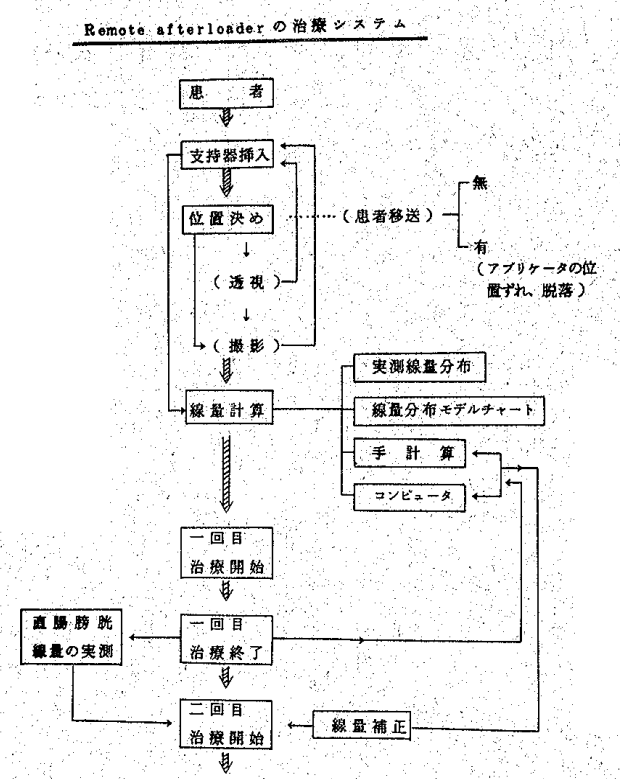

Fig. 6. Treatment system of remote afterloader.

\subsection{Water air ratio (WAR)}

WAR は，組織の吸収と build up を考虑したおのて Table 6 亿示ずような諸氏の報告がある. computer Dose Packは, 守本の式, Therac, Artronix には, Meisberger の式が使用されている.

Table 7 亿線源強度 $1 \mathrm{Ci}$ あたりの笑測值已近似弪算 值の比較を行った結果を示した． 線源から $1 \mathrm{~cm} の$ 点の 実測値と計算值との間では，約20\%の差を生じているが 諸氏の WAR を使用した計算值間には大差がない，

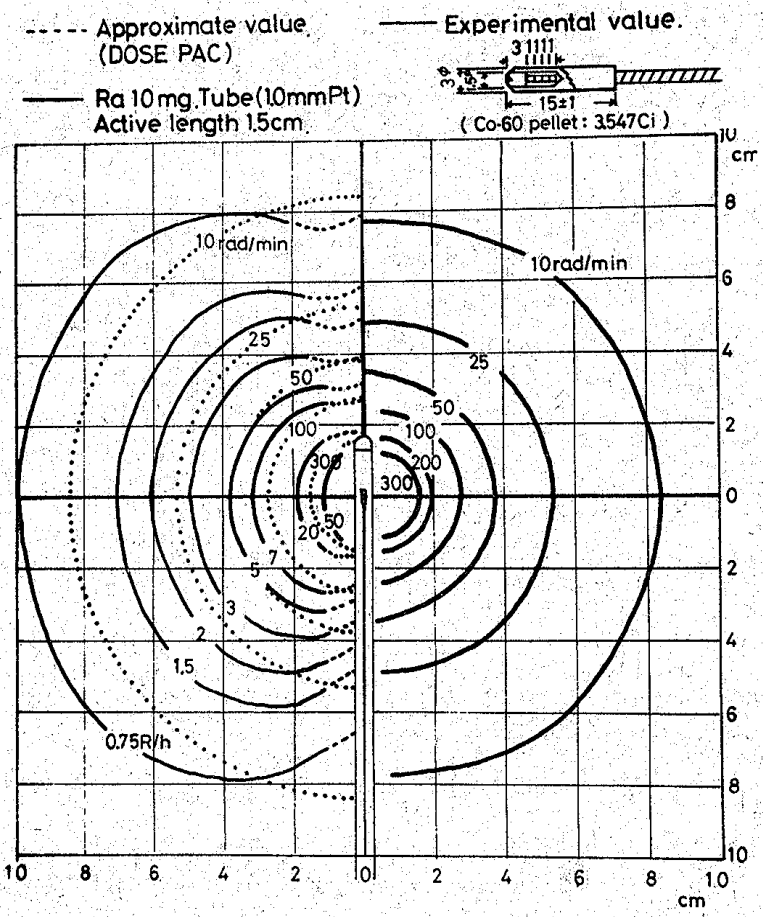

Fig. 7 Isodose curves measure in water round a tandem catheter containing a nominal 3. $54 \mathrm{Ci}{ }^{60} \mathrm{Co}$ pellet type source are shown on the right. On the left are shown. isodose curves in air round a radium source $(10 \mathrm{mg}$ radium tube, active length $1.5 \mathrm{~cm})$, and approximate value of nominal $3.54 \mathrm{Ci}{ }^{60} \mathrm{Co}$ pellet type source calculated by computer.

Table 5 Calculation of radiation dose. (Measurement value. Model chart. Calculation. Computer.) 線量計算方法の実際

\begin{tabular}{|c|c|c|c|}
\hline 奏測線量分布による方法 & 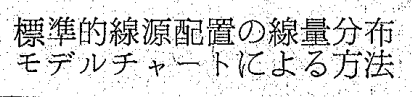 & 手計算による方法 & コンピュータによる方法 \\
\hline 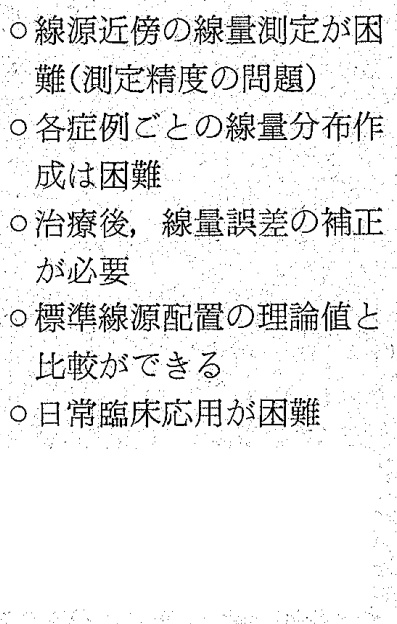 & 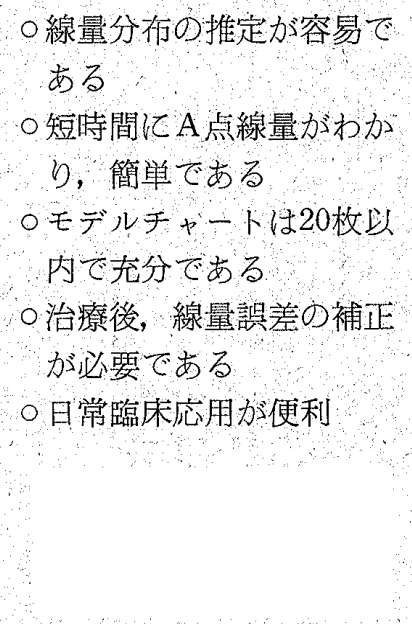 & 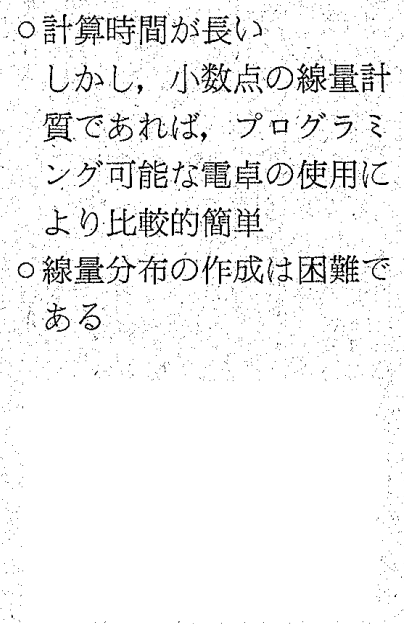 & 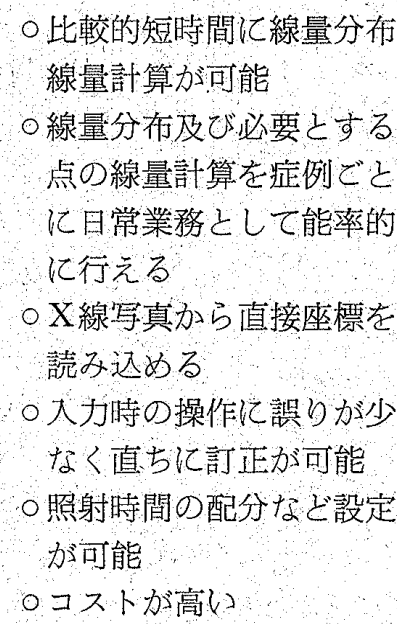 \\
\hline
\end{tabular}




\section{$7.2 \gamma$ 線放射定数 $(\Gamma)$}

${ }^{60} \mathrm{Co} \gamma$ 線放射定数は $1.32,1.35 \mathrm{R} / \mathrm{h}$ at $1 \mathrm{~m}$ があるが， computer の計算式には $1.35 \mathrm{R} / \mathrm{h}$ at $1 \mathrm{~m}$ 怔使用されて

Table 6 The approximate formula of water air ratio or $\mathrm{AB}$ factor by various investigators.

\begin{tabular}{|c|c|c|}
\hline Computer & Investigators & Approxinate formula \\
\hline DOSE PAC & Morimoto & WAR $=(I+\mu d) \exp (-\mu d)(\mu \mathrm{d}<\mathrm{I})$ \\
\hline $\begin{array}{l}\text { THERAC } \\
\text { Axtronix }\end{array}$ & Meisberger & $\begin{aligned} \mathrm{WAR}= & 0.99423-0.005318 \mathrm{~d}-0.0026 \mathrm{TOd}^{2} \\
& +0.0001327 \mathrm{~d}^{3} . \quad(\mathrm{I} \leq \mathrm{d} \leq \mathrm{TO} \mathrm{cm})\end{aligned}$ \\
\hline & Ponnuni kartha & $\begin{array}{c}A B=\exp (-\mu d) \exp \left(0.73 \mu d / E^{0.05}\right) \\
(0.255<E<2 \mathrm{Mev} . \quad 0<\mathrm{de}<\mathrm{T})\end{array}$ \\
\hline & $\begin{array}{r}\text { Goldstein \& } \\
\text { Wilkins } \\
\end{array}$ & $A B=\exp (-\mu d) \exp \left(0.77 \mu d / \mathrm{s}^{0.29}\right.$, \\
\hline & Batho \& young & WAR $=I-0.0074 \mathrm{~d}^{3 / 2}\left({ }^{226} \mathrm{RA}\right)$ \\
\hline$\cdots$ & onat: & WAR $=I-0.00116 \mathrm{Ta}-0,0004435 \mathrm{~d}^{2} .\left({ }^{226} \mathrm{Ra}\right)$ \\
\hline & Adams & WAR $=I=0.026 . \quad\left({ }^{226}\right.$ Ra $)$ \\
\hline
\end{tabular}

いる.

7.3 線源, および線源カプセルの吸收補正係数 $\left(e^{-\mu x}\right)$ 線源，および線源カプセルの吸収補正係数は，報告が 少なく，森本らが0.96と報告している。また，アプリケ 一タの材質による補正は現在のと乙ろ行われていない。

\section{4 線源送戻, over ride による寄与線量}

タンデムの往復時間を加味した任意の点における照射 線量率 $\dot{X}$ 乙照射時間 $t$ の関係を Fig. 8 亿示す。これは， テレコバルト装置のタイマの端效果と同様で, 図の斜線 部の奇与線量は各装置认固有の值である. タンデム線源 では，線源送戻時て及ぼす寄与線量は無視できるが， over ride による奇与線量は無視得なり場合があり，A 点 1 回線量, 線源強度, over ride の線源間隔などの影 響をうける。すなわち，線源強度が大きく， over ride 時の線源間隔が長く，線源送戻回数が多しにど寄与線量 の影響は大きい.
Table 7 The comparison of approximate values by various investigators to our experimental value about $1 \mathrm{Ci}{ }^{60} \mathrm{Co}$ source.

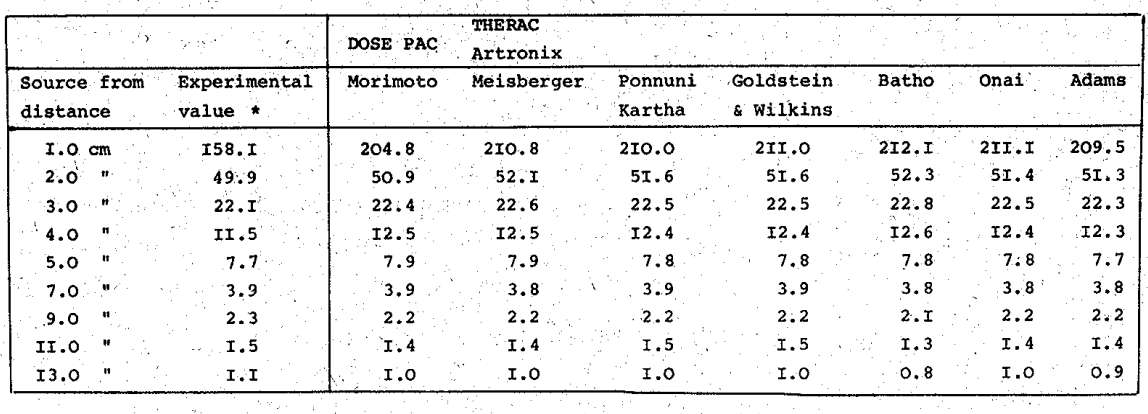

* Chamber : Radocon 555 probe roo IC

* $\mathrm{rad} / \mathrm{min}$. $($ in watex phantom

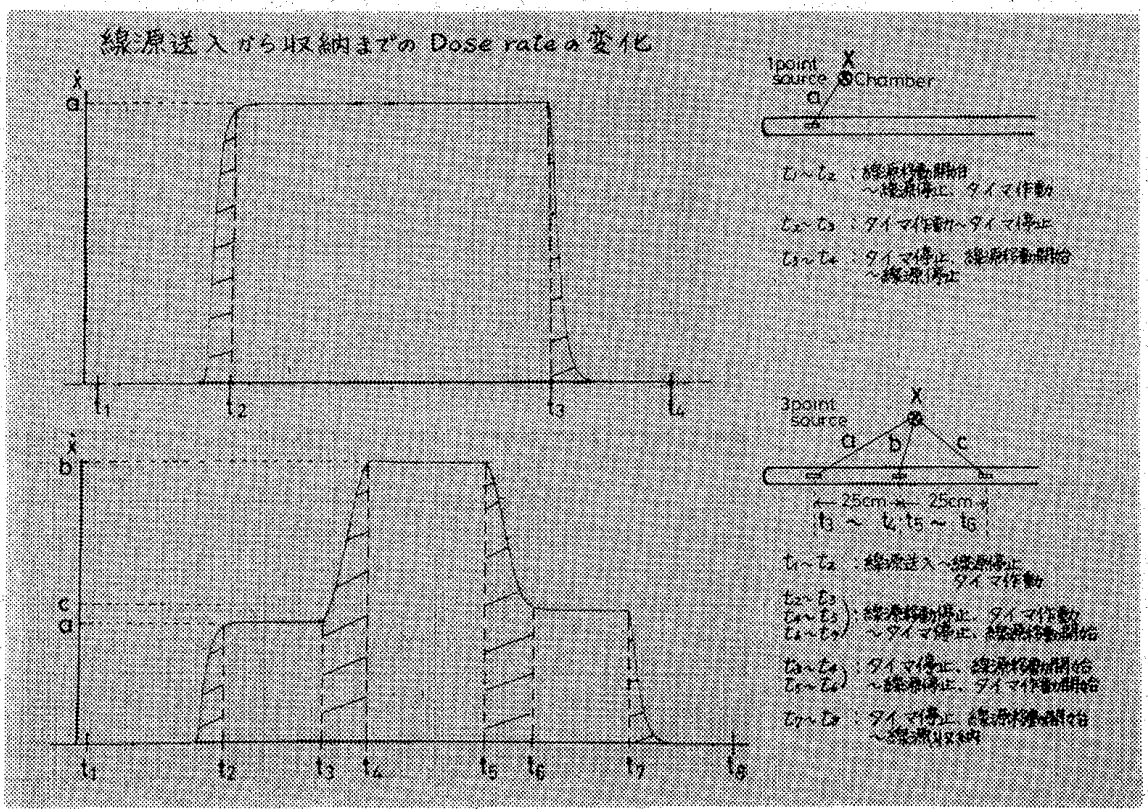

Fig. 8 The variation of dose rate with cycling source.

\section{8. 安 全 機 構}

Remote afterloader $の$ 機 構は比較的単純であるか， 治療精度の低下，被曝事故 の発生など危険な故障へ結 ぬ゙つく要因多多く，Table 8 亿示すような電気的，機 械的安全穖構吕付随してい 万.

安全機構乙しては，モ二 タチェンバなごによる線源 収納の安全機構，線源スり ップ検出機構，諸種の安全 接続穖構，照射室屝インタ ロック機構なざがあり，さ らに，望ましい安全機構と して,バック・アッッ゚・夕 イマの付設，停電時の非常 用電源，挍よび重垂などに よる自動線源収納機棈, 缧 急時の線源収納用の emergency switchなどが必要 である.

\section{9. 故障と対策}

故障には，二般的な故障 と被曝事故に結びつく陆険 
Table 8 Safety device and it's systems. 安全装置及び安全機棒

○被曝事故防止のため線源送居上の確笑かつ安全な電機 制御機構及び安全装置の設琹

\begin{tabular}{|c|c|}
\hline $\begin{array}{l}\text { 安全装置及 } \\
\text { ひ安全機構 }\end{array}$ & 内 \\
\hline $\begin{array}{c}\text { ○線源送戻及び叹 } \\
\text { 納の主全碓認 }\end{array}$ & 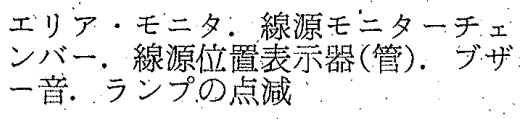 \\
\hline $\begin{array}{l}\text { 。線源スリップ倹 } \\
\text { 出機構 }\end{array}$ & $\begin{array}{l}\text { 線源送り出しの異賞発生による線源 } \\
\text { 動收納機種 }\end{array}$ \\
\hline $\begin{array}{l}\text { アプソケータ. } \\
\text { 照射器の接続安 } \\
\text { 全機構 }\end{array}$ & $\begin{array}{l}\text { アプリケーータを接続しないで線源送 } \\
\text { 戻が不可能な機構 }\end{array}$ \\
\hline $\begin{array}{l}\text { ○レーズ・ワイ } \\
\text { ヤ, 線源カプセ } \\
\text { ル継手の接続安 } \\
\text { 全機構 }\end{array}$ & 榮内管内で絶対にはずれない機構 \\
\hline $\begin{array}{l}\text { O箘内管, 線源容 } \\
\text { 器の接続安全機 } \\
\text { 構 }\end{array}$ & 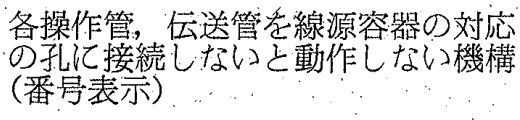 \\
\hline $\begin{array}{l}\text { ○ドアインタロッ } \\
\text { ク機構 }\end{array}$ & $\begin{array}{l}\text { ドアを閉じないよ動作しない機構 } \\
\text { 治療中のドア開きさるる線源自動収 } \\
\text { 納機構 }\end{array}$ \\
\hline ○手動ハンドル : & 緊急非常時，停電時 \\
\hline $\begin{array}{l}\text { バック・アップ } \\
\text { ・タイマ }\end{array}$ & 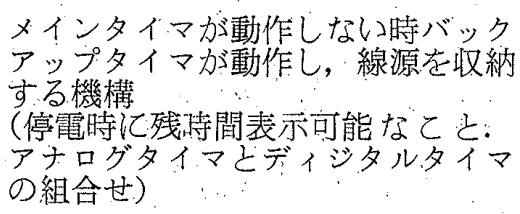 \\
\hline $\begin{array}{c}\text { ○線源自動収納機 } \\
\text { 構 }\end{array}$ & 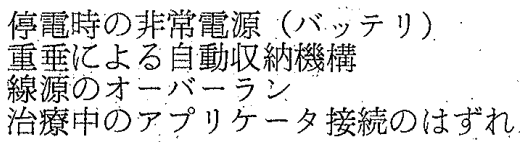 \\
\hline $\begin{array}{l}\text { Emergency } \\
\text { Switch }\end{array}$ & $\begin{array}{l}\text { 緊念時の線源収納穖構 } \\
\text { (制御器・線源容器て設賢) }\end{array}$ \\
\hline
\end{tabular}

な故障とがあり，原因としては，装置の経年変化などに よる電気的; 機械的な故障, メーカカの設話，製作の誤り, 使用者の取扱上の不注意による誤操作などがある.

\section{1 一般的な故障}

Fig. 9亿示すような一般的な故障は，線源送戻上の故 障が多く，案内管の彎曲，たるみ，破損，レリーズ・ワ イヤのケバ立ち，線源ワイヤの接続部の故障，.アプりケ 一タの損第, 照射器とアプリケータの接続部のガタ，電 気的な故障などがある。

案内管接続部[1]は，案内管の彎曲のため線源送戻によ るガタを生じやすく，日金部之案内管の離脱の原区とな る…治療台に固定されている照射器では，乙れの可動範 囲が小さいととから，䓩内管未端部国の折損の原因とな るため，治療台から切り難す移動形の方が望ましい。之

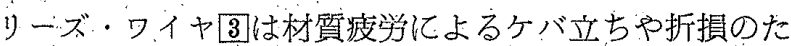
め，線源収納が不可能になることもある．線源ワイヤ接 続部田は案内管内で離脱しない構造になるているが，ア プリケータの接続ミスがあった場合はしの部の離断を生 じる颃それがある、アプリケータ可はポリエチレシチュ ーブの折損，“また，接続部は口金の材質不良や製作えス によりガタを生じることあある。線源収納容器のマイク ロスイッチの作動不良により；電気的な線源送实が不可： 能なとと屯ある，以上の線源送厌上の故障を減少させる には，案内管を直線状にずべきであり，したがって，治 療室は外部照射装置などと併設しないととが望ましい。

線源位置ずれは，アプりケー夕のポリエチレンチュー ブの製作えス，または，ゴえ付着などによる照射器内部 冈マイクロスイッチ拥䤧の作動不良があり，グリース注

入などにより解決される。

その他の故障として，リ 一ク，放射線椇傷によるも ニタ:チェンバの故障（チ エンバのデシケータの保管, 除湿機の設置); タイマの 故障 (バッタ・アップ・タ イマの件哜)，線源移動表 示のズレ，表示灯，警告灯 の故障，送戻用駆動ローラ の摩耗など成ある。

\section{2 危険な故障}

被樭事故を発生する伦険 な故障とは，線源の線源仪。 納容器への收納が不可能な 埸合である。との原因とし

Fig. 9 Eqipment troubles and their countplants. 
て，(1)電気的，機械的に線源引き戻しが不可能，(2)線源 封入カプセルとレリーズ・ワイヤ継手の離断，执よび破 損, (3)レリーズ・ワイヤの断線, (4)線源の破損による涯 染，(5)使用者の取圾上の不注意など为洘えられる。乙れ らの故障は，使用者に不要な放射線被㫽を生し，患者に は過線量照射の传険をもたらす。をこで，日常の保守管 理，職員のダブルチェックによる確認，教育，訓練を合 めた高度な安全管理による了防対策を要し，さらに故障 の発生時に，患者をすみやが退出させるなどの緊急事 故対策を設けなければならない。

\section{0. 保 守管理}

保守管理は，放射線診療業務の円滑な運営をはかり， 正確な治療線量の制御，患者に対する安全性，故障の未 然防此，環境安全対策を施すととにあり，自主管理（日 常点検，定期点検）と保守琶約による管理加むる。

日常の保守点検は，Table 9 亿示すようなアプりケー 夕の異常確認，使用線源の接続確誌，表示ランプ,メー
Table 9 Daily check points.

日常(治療前)の保守点検

\begin{tabular}{|c|c|c|}
\hline & 保守点検項目 & 保封点检内容 \\
\hline 照射器関係 & アプリケータの磼認 & 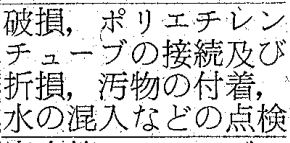 \\
\hline \multirow{2}{*}{ 線源收納容器 } & 使用線源の接続確認 & $\begin{array}{l}\text { 案内管，レリーズワ } \\
\text { イヤの接続点検 }\end{array}$ \\
\hline & $\begin{array}{l}\text { リレー゙ワイヤと線 } \\
\text { 源カプセル継手の接 } \\
\text { 続確認 }\end{array}$ & $\begin{array}{l}\text { ショイントのゆる } \\
\text { み, カシメ状態の買 } \\
\text { 常などの有無の点検 }\end{array}$ \\
\hline \multirow{2}{*}{ 制御器関係 } & \begin{tabular}{|l} 
線源送戻の電気的, \\
手動的動作の碓諗
\end{tabular} & $\begin{array}{l}\text { 線源ランニングの異 } \\
\text { 常の有無 }\end{array}$ \\
\hline & 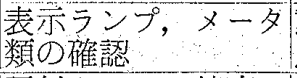 & \begin{tabular}{|l} 
動作の異常の有無の \\
点検
\end{tabular} \\
\hline タイマ関係 & 照射タイマの精度の & 異常の有無の点検 \\
\hline チェンバ関係 & 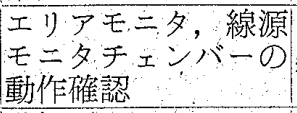 & 異常の有綮の点検 \\
\hline 監視装置関係 & 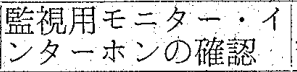 & 異常の有無の点検 \\
\hline $\begin{array}{l}\text { 位置決め攝影 } \\
\text { 装置 }\end{array}$ & \begin{tabular}{|l|}
$\mid$ 位置決め撮影装置の \\
動作確認
\end{tabular} & 異常の有归の点検 \\
\hline
\end{tabular}

定期保守点检(その 1 )

Table 10 (a) Regulary check points.

\begin{tabular}{|c|c|c|c|}
\hline & 定期保守点检項自 & 定期保守点㭘内容 & 期 間 \\
\hline \multirow{5}{*}{ 照 射 器 } & $\begin{array}{l}\text { 線源 “ON” 位置信号用マイクロスイッ } \\
\text { ○動作 }\end{array}$ & $\begin{array}{l}\text { 損傷，線のはずれから，アクチェータの変化 } \\
\text { 及び動作状態など }\end{array}$ & 6 力月: \\
\hline & 各クィックカプリング部の動作 & 案内管, アプリケータ接続による機能 & 6 力月 \\
\hline & オーバライド部の動作 & $\begin{array}{l}\text { マイクロスィッチの損傷, モータの動作ポ } \\
\text { テンションメータの抵抗值の変化 }\end{array}$ & 6 力月 \\
\hline & $\begin{array}{l}\text { レリーズワイヤと線源カプセル継手の接続 } \\
\text { 確認 }\end{array}$ & 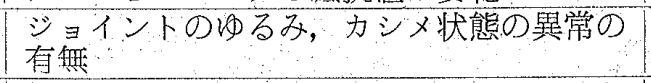 & 每 日 \\
\hline & 各部固定ッマミの動作 & 確害な固定，解放 & 6 力月 \\
\hline \multirow{7}{*}{ 線源収納容器 } & 各信号用マイクロスイッチの動作 & マイクロスィッチの損傷，線のはずれかけ & 6 力月 \\
\hline & 各端子接続部 & ネシシのるタ，線のはずれかけ & " \\
\hline & カプセルロック機構の動作 & 線源の漏出の有無 & $"$ \\
\hline & 模捄線源駆動部選択用スィッチの動作 & スィッチの損傷, はずれかけ & " \\
\hline & 各クイックカップリング部の動作 & 異常の有無 & "1 \\
\hline & 各部のネジのるみ & ゆるみ & $" 1$ \\
\hline & 漏浑線量測定 & $\cdots$ & 6 力月 \\
\hline 桑 内管 & 案内管 & 折損，口金部の取付 & 6 力月 \\
\hline \multirow{7}{*}{ 操 作 䀰 } & リレーズワイヤ送送用ハスバギヤ & キズ, 油切れ, ピッチの変形，ゴ々付着 & 6 力月 \\
\hline & レリーズワイヤ及びチェーン & ゆるみギズ油切れ変形，ゴる付着 & 6 力月 \\
\hline & 送戻用切換えタラッチの動作 & 起電中，移動中の電压調整 & 6 力月 \\
\hline & 遅䃌りレー，電磁りレ & 接点あれ，取付ネジのゆるみ & 6 力月 \\
\hline & 各端子接続部 & ネジのゆるみ，線のはずれかけ。 & 6 力月 \\
\hline & カウンタ駆動用ベベルギャ，軸受 & 注油，ゴ之，ほとり，軸受の焼付 & 6 力月 \\
\hline & 手動ハンドル & 動作確認 & 毎 日 \\
\hline
\end{tabular}


Table $10(b)$ Regulary check points.

定期保守点検(その 2 )

\begin{tabular}{|c|c|c|c|}
\hline & 定 期 点 検 項 目 & 定 期 点 愉 内 容 & 期, 間 \\
\hline \multirow{7}{*}{ 制 御 器 } & 各端子接続部 & 取付ネシのゆるみ，線のはずれかけ & 6 力月 \\
\hline & 各表示灯, 押し釗, キースィッチの動作 & 異常の有與 & 每 $\mathrm{日}$ \\
\hline & 線源移動表示器 $メ-タ$ & 移勤距䌖の表示 $\sigma$ 一致 & 玨 日 \\
\hline & 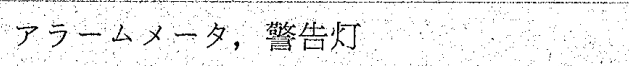 & 表示灯の点滅 & 毎 日 \\
\hline & $\begin{array}{l}\text { カウンタ駆動用フレキシブルシャフト及ひ } \\
\text { 軸受の点検 }\end{array}$ & 異常の有無 & 6 力月 \\
\hline & オーバライドの精度 & $\begin{array}{l}\text { 引きもとし間隔, ポテンションメータの点 } \\
\text { 榆 }\end{array}$ & 6 力月 \\
\hline & 送底用, 䭾動, 诞動口-5 & 摩 耗 & 6 力月 \\
\hline \multirow{2}{*}{ 间路タ-ロッタ } & スリップ検出機棲 & 作㗚D良甭 & 每 日 \\
\hline & ドア, スィ, & 作動の良否 & 毎 日 \\
\hline \multirow{2}{*}{ 線 量 計 } & 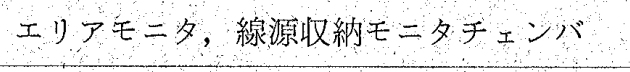 & 異掌の有無 & 毎 日 \\
\hline & 線源収納モータチェンバの較正 & & 3 力月 \\
\hline \multirow{2}{*}{ 監 視 装 置 } & 監視用 $モ 二$ 多 & 異常の有烸 & 1 力月 \\
\hline & 1ンターホン & 異常の有無 & 1 力月 \\
\hline \multirow{2}{*}{$\begin{array}{l}\text { 位置決为撮影装 } \\
\text { 置 }\end{array}$} & 位置決め撮影装置 & 異常の寿與 & 6 力月 \\
\hline & 治療用浸台 & 異常の有舆 & 6 力 \\
\hline \multirow{4}{*}{ そ $\sigma \quad$ 他 } & 出力測定 & 空閒線量の測定 & 3 力月 \\
\hline & 線源位罝の確認 & 精度雃認 & 1 力 \\
\hline & 照射時間 & & 1 为月 \\
\hline & 送因回数 & & 1 力月 \\
\hline
\end{tabular}

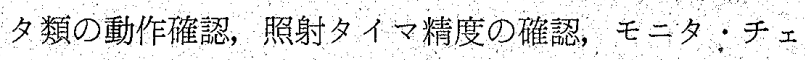
ンパの動作確認, 監視用モニタ，および位置決め撮影装 置の動作確認などを行うへきである.

定期点検は， メーカとの保守契約とより行うのか理想 的であるが，自主定期点検を行う場合は，Table 10(a)， (b) 亿示すようなチェックコトを作成する必要加 る. 特と, 出力測定, 楾源位置ズレの確認は重装で z.

\section{JIS 規格等について}

Remote afterloader は，装瞋の安全性確保，保管理 を円滑にするための JIS, JESRA, IEC などの工業 標蕉 化の制定がなされていないのか現状である.

そこて, Table 11 亿示すような内容てついて, JIS, IEC 委員会での早急な検討が望まれる.

\section{2. 治療室の防護の問題点}

治療室防護の問題は，Table 12 亿示すようと線源 が 裸出するため, 治療室六面体全部を利用線錐として防護 しなければならない。また，誤操作による偷性を考慮 し，他の治潦装置と併設しなりこしが望ましく，科学技 術庁がメーカに対して口頭による指尊を行っている. そ の他, 考慮すべきしとは, 午容線量，使用時間の制限, 線源の放射能，遮蔽計算などがある.またテレコバル 卜装置は，装置機構上，二次線のみて解沠され，一方， Remote afterloader はこれに一次線を加えて考虑しなけ れはならない。そしで，車者は同等な隔壁の厚さ，もし くはRemote afterloader の方加より縓重な防護壁を必 要とする.

Fig. 10 は, Remote afterloader の治療室の一例でめ 
Table 11 Contents to settle the industrial standard.

JIS 規格等の制定

○安全衛生の確保や消費者保護のため,JIS(日本工慈䙺 格)，JESRA(日本放射線機化工業規格)，IEC(国際電 気標準会議)なざの工莱準供化の制定が必要 OJIS, IEC 委貣会による検討

\section{-}

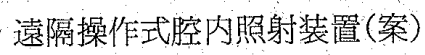

1. 適用筙用

2. 用語の意味

遠隔腔内治療装置, 線源, 線源収納容器, 定格, 最大許容量, アプリケータ,オーバライド方式, 治療台，照射術式，模擬線源

3. 電源設備及び接地設備 電源設備（電源の相数，電源の周波数，定格負荷 通電中の許容電源，電圧範井), 接地設備

4. 性 能 治療台の人体支持部の強度，電気回路の耐電圧， 絶縁抵抗，放射線防護(非常射時の漏れ線量率)

5. 構 造

電源端子，電源導線の公称断面積，接地端子及び 接地線, 差し込み接続器, 外装及び保謢为バー, ヒューズ及び配線用しゃ断器，表直・角・縁，停 電時の危険防止，線源スリップ検出安全機構，放 射線防護（線源収納容器の構造）線源の送戻, 線 源自動収納機構，手動ハンドル，照射中の表示， 案内管，アラームメー夕，線源収納モニターチェ ンバ, バック・アップタイマ, 操作器, 制御器, 電源箱，模擬線源

6. 試験方法 試験条件，電源防此試験（外装漏㣗電流試験，電 気(抵抗試嗝) 面電生試験，絶縁抵抗試験，治療台 の安全体量試験，非照射漏れ線量率試験，線源自 動収納試験，線源位置確認試験

7. 表 示

装置の形式はその名称，製造業者及び住所，製造 ，番昂，据付年月日又は製造年月日，定格，定格電 源の相数 - 電压及ざ周波数，消費電力，標識

8. 取扱上の注意

9. 定期点検及びオーバーホール 定期点検項目及びその期間，オーバーホール

る。治療室は, 線源収納容器, 治療台, 位置決装置な

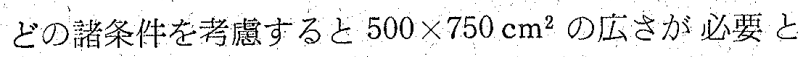
なる。

\section{3. 結一語}

Remote afterloader の臨床応用に際し，線源の送戻が
Table 12 The radiological protection for the remote afterloader.

Remote afterloader 治潦室のしゃへい

(考慮すべき問題)

1.「六面体全部を利用線維方向として防護しなりれば ならない」

2. Remote afterloader と他治療装置の併設をしない ことか望ましい。

（誤操作による患者の危険性を考慮）

「科学技術庁がメーカに対して口頭にて指導（昭和 51年)」

○新設の施設……原則として一治療室に一治療 装置

○増築のスペースがなり場合……特例的に認可 するとと屯ある.

(条件)……各治療装置相互間のインタ， ックの設置

……表示灲とドアインタロックを 共通

3. 漏浅線量率の適用される場所（許容線量）

○使用施設内の人が常時立ち入る場立 $\cdots \cdots 100$ $\mathrm{mrem} /$ week

。病院内の境界, 又は病院内の人が居住する区域 ....10 $\mathrm{mrem} /$ week

○病院又は誩療所の病室 $\cdots . .130 \mathrm{mrem} /$ week

○管理区域…3.30 merm/week

4, 使用時間の制限

○1週間あたりの姃べ使用時間の制限

○1週間あたりの姃べ使用時間は 24 時間未満に 制限しても $4 \mathrm{merm} /$ week を越えてはならな ( ) (医療法施行規則30条 6 )

5. 線源の放射能

同時使用線源の最大量

（組合せ可能な線源 3 個の合計量の最大……使用 線源量）

6. しゃへ认計算

○治療室の隔壁等の所要壁厚の計算

○漏洩線量率の計算(画壁の透過率より求める法) ○迷録部分の散乱線

7. Remote afterloader ¿ Tele- ${ }^{60} \mathrm{Co}$ 装置について o Remote afterloder..... - 次線 $(4 \pi$ 方向)，散 乱線

o.Tele ${ }^{60} \mathrm{Co}$ 装置……次線 (一方向の一次線維)

支障なく行われ，治潦精度の向上に努めるてとが我々の 義務であり，そのためには，治䝤設備に応じた最良の腔内 照射法の確立と最善の保守管理を行わなければならない。

さらに, Remote afterloader 治療をより完全なものに 


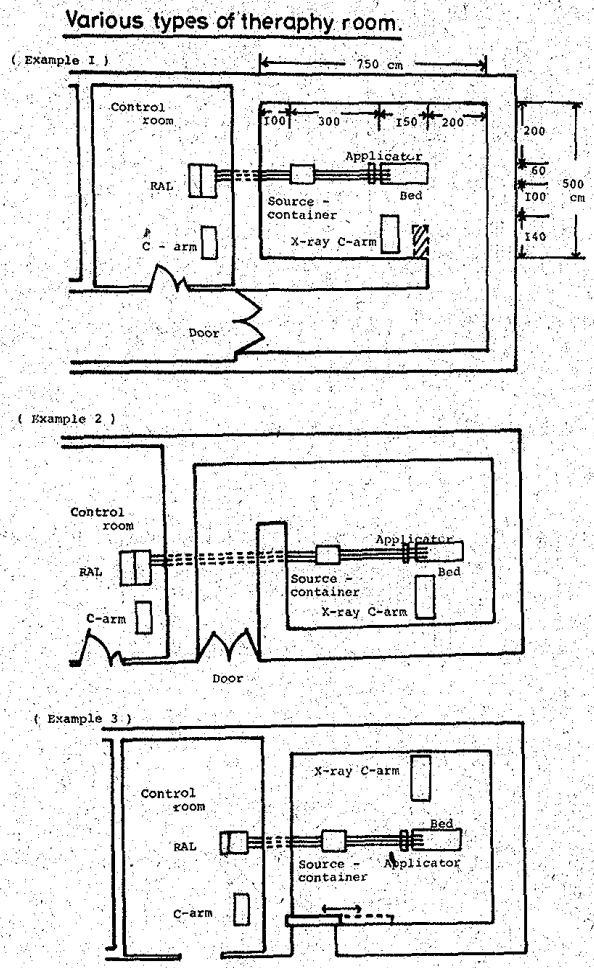

Fig, 10 Various types of treatment room.

するには，(1)適切な照射を行える施設と職具（放射線治 療䀢, 放射線物理学者, 放射線技師, お上ひ研究活動。 できるチーム)，老備えていることが必要で，(2高度な 安全管理之職貝の被曝防止対策が完全で，(3)研修プログ ラム, 教育指導システムを作成し，乙れを国際的な水隻 で实拖すべきである。

\section{(謝辞)}

稿を終えるに当り，発表の機会を与えて頂きました焈 会長，座長てお礼を申したげると共に，御指導，御校閲 下さいました高山一雄部長，御協力下さいました村田迪 夫技師，そして私信等しよって，御教授下さいました爷 病院放射線技㸝諸见，並びに各メ一力担当者に感謝致し ます.

\section{文 献}

1) Henschke, U. K., et al.: Afterloading in interstitial and Intracavitary Radiation Theraphy. Amer. J. Roent., 90, 386-395, (1963).

2) Henschke, U. K. . Remote Afterloading with Intracvitary Applicators. Radiology, $\mathbf{8 3}(2), 345-346$, (1964).

3）若林 勝，他：遠隔操作式 afterloading 装置 0 試 作. 臨朱放射線, 11(8), 678-684, (1975)。
4)ラシオアイソトープ(密封線源しその取扱).（線源， 130-138，日本放射性同位元素協会綆

5) 橋本省三，他：高線量率腔内照射法. 痬の臨床別刪, 93-97. (1978), 篠原出版.

6) 熊谷孝三，他：Remote afterloader について.日放 技，九州部会拸録集，(1976).

7) 熊谷孝 $=$ ，他: Remote afterloader lCつして（第 2 報)、、日放技九州部会抄録集，(1978).

8）襎用中小量 $\gamma$ 線源。アイソトープニース, $31-32$, (1975).

9）日崎瑛生：日常診療に於ける子宮頙癌腔内照身の2, 3 O間題点. 産科乙婦人科, $41(5), 645-654$, (1966).

10) A. V. Santhamma: Determination of total activity and its distribution in cathetron source pencils. Strahlentherapie, 154, 776-779, (1978).

11) 日崎瑸生，他：子営頸癌腔内照射用支持器飞つ飞 乙. 踹床放射線, $768775,(1965)$.

12）传方周防，他：子宮頸癌の离線量率腔内照射法の線 量分布执よび治療スケシュールに関する一考察，日 医放学誌, 39(7), 727-736, (1979).

13) Adams, G. D. and Meurk, M. L.: The use of calculate isodose information sorrounding distributed gynaecologcal radium source. Phy. Med. Biol., 9, 533-540, (1964).

14) H. F. Batho and J, Young: Tissue absorption correction for linear radium source. Brit. J. Radiol, 37, 689-692, (1964)

15) J. Young and H. F. Batho: Dose table for linear radium source calculated by an electronic computer. Brit. J. Radiol, 37 (433), 38-44, (1964).

16) K. I. Ponnunni Karrha, et al.: An experimental determination of the absorption and build up factor in water for radium, cobalt-60, ceasium- 137 gamma-ray. Am. J. Rentgenol, 96, 66-69, (1966).

17) W. J. Meredith, et al. The attenuation and scattering in phantom of gamma-ray from some radionuclides used in mold and interstitial gammaray therapy. Brit. J. Radiol, 39, 280-286, (1966).

18) Klevenhagan: An experimental study on the dose distribution in water around ${ }^{137} \mathrm{C}$ s tubes used in brachytherapy. Brit. J. Radiol, 46, 1073-1082, (1973).

19) Suit, H. D, Moore, E, B. and Fletcher, G. H.: Modification of Fletcher Ovoid System for Afterloading using Standard-Sized Radium Tubes (Mil- 
ligram and Microgram). Radiology, 81, 126-131, (1963).

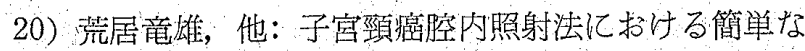
線量推定について．産婦人科の治療，11(3)，277 283, (1965.9).

21）町田孝子：電子計算機による子宮頸癌腔内照射の線 量分布の計算とその諳価。 日疾放学誌， $\mathbf{3 0}(1) ， 33-$ 45, (1970).

22）内山幸男，他：小型電算機儿よるラジム線源の線 量分布計算. 日放技学誌, 32(4)，368-374，(1976).

23）尾内能夫，他：ラジウム治療に掠ける線量分布の計 算。 日医放誌，28，1629-1635，(1969).

24）高田昼雄：密封小線源の簡算な線量計算。日放技学 詰, $33(4), 433-437,(1977)$.

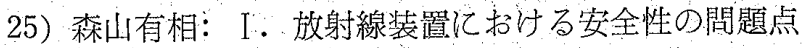
(䛦断用X線装置の機械的安全性)。日放技学誌， 33 (4), 444-453, (1977).

26）雄川港行，他：四．放射線機器管理にお㳡万安全性
の問題点（主として電気的安全性について）。日放 技学誌，33(4)，454-462，(1977).

27) 横山 俊：III. 放射線機器管理に抒ける安全性の間 題点（Human Factor について)，日放技学誌，33 (4), 463-468, (1977).

28）中鹿正明：IV. 放射線機器管理に打引る妍全性の問 題点 (国際規格面より芫た放射線機器の安全性).日 放技学誌，33(4)，469-482，(1977).

29）和久井聖：III。放射線治療装置の保守管理。日放技 学誌, 34(5), 608-615, (1978).

30) JIS Z 4608 (1974): コバルト60遠隔治潦装置. JIS ハンドブック放射線(能)，日本規格協会.

31）医療法施行規則，電離放射線障害防止規則，放射性 同位元素等による放射線障害の防止に関する法令集， 日本アイソトープ協会。

32) 橋本省三：Remote afterloading 飞よる陵内照射療 法. RADIOISOTOPES. 29(4), 39-46, (1980). 